\title{
THE AMERICAN EXPEDITIONARY FORCE SIBERIA: A CASE STUDY OF OPERATIONAL ART WITH AMBIGUOUS STRATEGIC OBJECTIVES
}

A Monograph

by

MAJ John K Price

United States Army

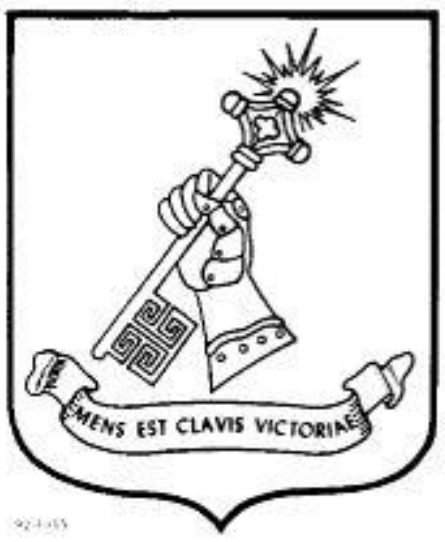

School of Advanced Military Studies

United States Army Command and General Staff College

Fort Leavenworth, Kansas

2014-01 


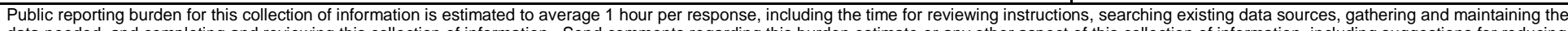

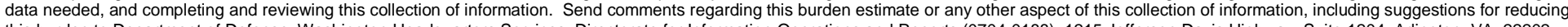

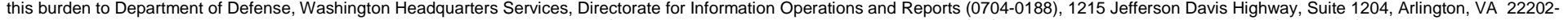

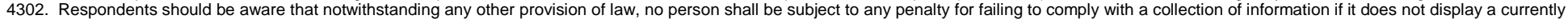
valid OMB control number. PLEASE DO NOT RETURN YOUR FORM TO THE ABOVE ADDRESS.

\begin{tabular}{l|l|l}
\hline 1. REPORT DATE (DD-MM-YYYY) & 2. REPORT TYPE & 3. DATES COVERED (FrOm - TO)
\end{tabular}

22 MAY $2014 \quad$ Master's Thesis

4. TITLE AND SUBTITLE

The American Expeditionary Force Siberia: A Case Study of Operational Art with Ambiguous Strategic Objectives

Ja. CONTRACT NUMBER

5b. GRANT NUMBER

5c. PROGRAM ELEMENT NUMBER

6. AUTHOR(S)

Major John K. Price, U.S. Army

5d. PROJECT NUMBER

7. PERFORMING ORGANIZATION NAME(S) AND ADDRESS(ES)

School of Advanced Military Studies

5e. TASK NUMBER

5f. WORK UNIT NUMBER

250 Gibbon Ave.

Ft. Leavenworth, KS 66027

9. SPONSORING I MONITORING AGENCY NAME(S) AND ADDRESS(ES)

8. PERFORMING ORGANIZATION REPORT NUMBER

U.S. Army Command and General Staff College

ATTN: ATZL-SWD-GD

Fort Leavenworth, KS 66027-2301

11. SPONSOR/MONITOR'S REPORT NUMBER(S)

\section{DISTRIBUTION I AVAILABILITY STATEMENT}

Approved for Public Release; Distribution Unlimited

13. SUPPLEMENTARY NOTES

\section{ABSTRACT}

According to current Army doctrine, operational art is the pursuit of strategic objectives through the arrangement of tactical actions in time, space, or purpose. Furthermore, doctrine and theory agree that these strategic objectives should be clearly defined and attainable. They suggest that the national level leadership will provide the operational commander with clearly defined strategic objectives prior to the commencement of any military operation. However, history shows that may not be the case and commanders should expect ambiguous strategic objects that are subject to change. Current doctrine fails to identify an adequate process for assisting the operational commander in situations with ambiguous strategic objectives. This raises the question: can a commander practice effective operational art under such conditions?

This purpose of this monograph is to provide insights to the operational artist planning a military operation with ambiguous strategic objectives. The monograph begins with a discussion of the theoretical background current doctrine of operational art specifically focusing on the strategic objectives. Having described a theoretical process, this monograph looks at the operational art of American Expeditionary Force in Siberia (AEF-S) during the Russian Civil War. The paper details the AEF-S operations throughout its twenty-month campaign. This paper concludes with a critical analysis of Graves's ability as an operational artist.

15. SUBJECT TERMS

\begin{tabular}{|c|c|c|c|c|c|}
\hline 16. SECURIT & LASSIFICATION & & 17. LIMITATION & 18. NUMBER & 19a. NAME OF RESPONSIBLE PERSON \\
\hline $\begin{array}{c}\text { a. REPORT } \\
\text { (U) }\end{array}$ & $\begin{array}{c}\text { b. ABSTRACT } \\
\text { (U) }\end{array}$ & $\begin{array}{c}\text { c. THIS PAGE } \\
\text { (U) }\end{array}$ & (U) & 49 & 19b. TELEPHONE NUMBER (include area code) \\
\hline
\end{tabular}




\section{MONOGRAPH APPROVAL PAGE}

Name of Candidate: MAJ John K. Price

Monograph Title: The American Expeditionary Force Siberia: A Case Study of Operational Art with Ambiguous Strategic Objectives

Approved by:

Gerald S. Gorman, Ph.D. Monograph Director , Seminar Leader

Uwe F. Jansohn, COL

Director, School of Advanced Military Studies

Henry A. Arnold III, COL

Accepted this 22nd day of May 2014 by:

Robert F. Baumann, Ph.D.

, Director, Graduate Degree Programs

The opinions and conclusions expressed herein are those of the student author and do not necessarily represent the views of the US Army Command and General Staff College or any other governmental agency. (References to this study should include the foregoing statement.) 


\section{ABSTRACT \\ THE AMERICAN EXPEDITIONARY FORCE SIBERIA: A CASE STUDY OF OPRATIONAL ART WITH AMBIGUOUS STRATEGIC OBJECTIVES, by MAJ John K. Price, U.S. Army, 44 pages.}

According to current Army doctrine, operational art is the pursuit of strategic objectives through the arrangement of tactical actions in time, space, or purpose. Furthermore, doctrine and theory agree that these strategic objectives should be clearly defined and attainable. They suggest that the national level leadership will provide the operational commander with clearly defined strategic objectives prior to the commencement of any military operation. However, history shows that may not be the case and commanders should expect ambiguous strategic objects that are subject to change. Current doctrine fails to identify an adequate process for assisting the operational commander in situations with ambiguous strategic objectives. This raises the question: can a commander practice effective operational art under such conditions?

This purpose of this monograph is to provide insights to the operational artist planning a military operation with ambiguous strategic objectives. The monograph begins with a discussion of the theoretical background current doctrine of operational art specifically focusing on the strategic objectives. Having described a theoretical process, this monograph looks at the operational art of American Expeditionary Force in Siberia (AEF-S) during the Russian Civil War. The paper details the AEF-S operations throughout its twenty-month campaign. This paper concludes with a critical analysis of Graves's ability as an operational artist. 


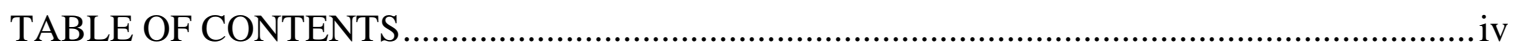

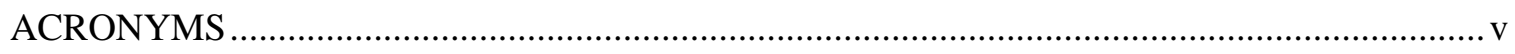

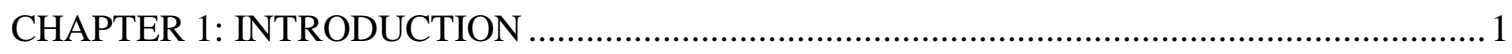

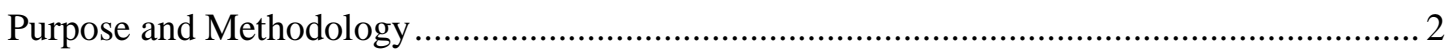

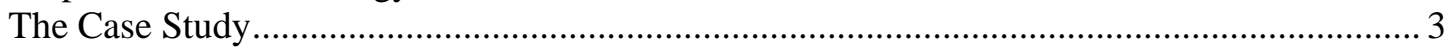

CHAPTER 2: OPERATIONAL ART WITH AMBIGUOUS STRATEGIC OBJECTIVES ......... 5

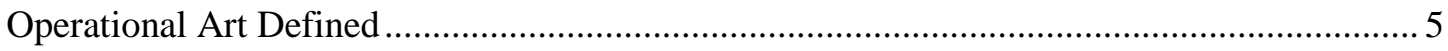

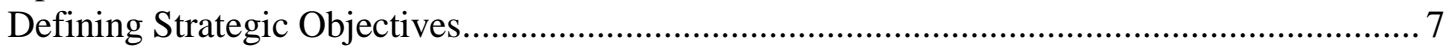

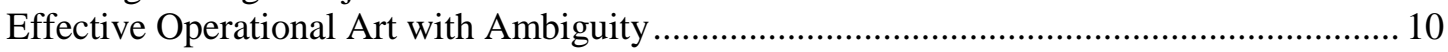

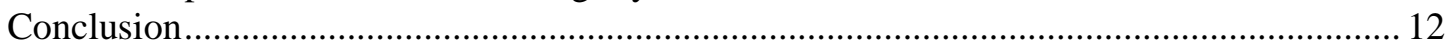

CHAPTER 3: THE AMERICAN EXPEDITIONARY FORCE SIBERIA ................................ 13

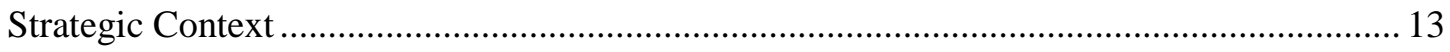

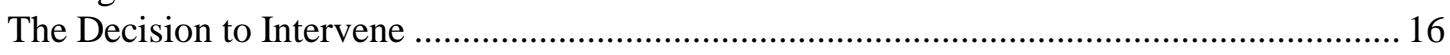

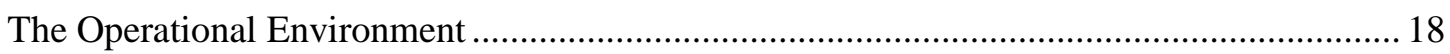

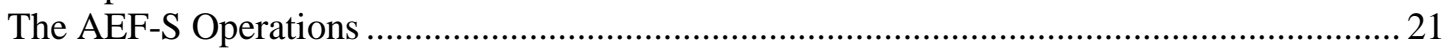

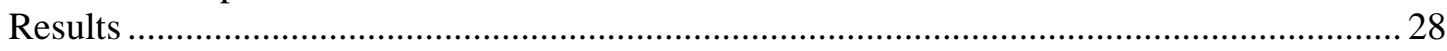

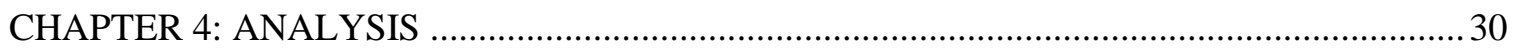

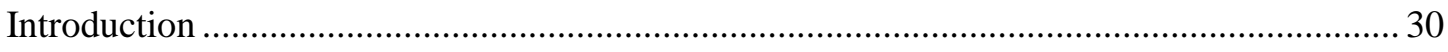

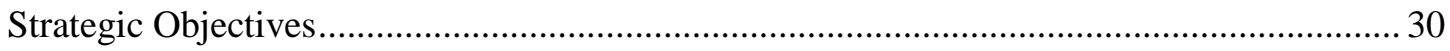

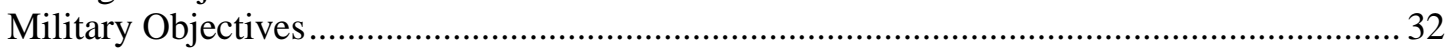

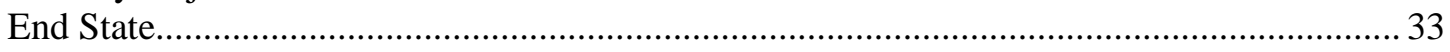

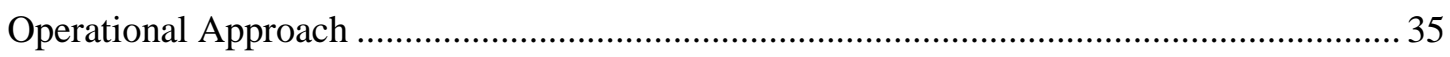

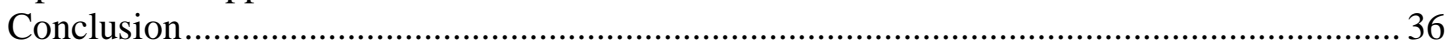

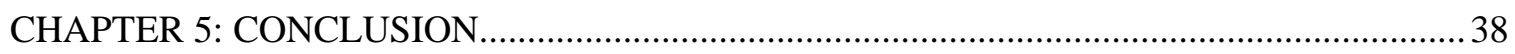

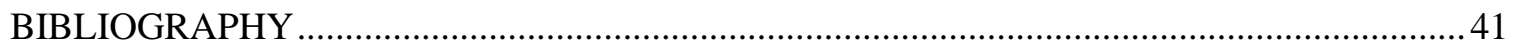




\section{ACRONYMS}

$\begin{array}{ll}\text { ADP } & \text { Army Doctrinal Publication } \\ \text { ADRP } & \text { Army Doctrinal Reference Publication } \\ \text { AEF-S } & \text { The American Expeditionary Force Siberia } \\ \text { JP } & \text { Joint Publication } \\ \text { RRSC } & \text { The Russian Railroad Service Corp } \\ \text { SecDef } & \text { Secretary of Defense }\end{array}$




\section{CHAPTER 1: INTRODUCTION}

The political object-the original motive for the war-will thus determine both the military objective to be reached and the amount of effort it requires. ${ }^{1}$

Carl Von Clausewitz, On War

The question this paper will examine: is can a military commander practice effective operational art with ambiguous strategic objectives? Since the United States Army adopted the concept of operational art in its doctrine, the Army has focused on linking tactical actions on a battlefield with achieving strategic objectives. According to the latest version of American Army doctrine, operational art is "the pursuit of strategic objectives, in whole or in part, through the arrangement of tactical actions in time, space, or purpose." ${ }^{2}$ While this definition may seem overly simplistic, there is in fact a deeper meaning of operational art. The definition implies a clear understanding of strategic objectives. Additionally, this definition of operational art seems to imply that those strategic objectives are both tangible and attainable through military force. Current American doctrine and historical literature both support the idea that military commanders must focus their operations towards clearly defined objectives. One popular school of thought, the Weinberger doctrine, is built upon the notion that military force should only be used with clearly defined military and political objectives that are achievable with an appropriate level of force. ${ }^{3}$ However, history has shown that governments have used military force towards ambiguous or unattainable strategic objectives. A great example of this phenomenon is the American intervention in the Russian Civil War, which is the case study of this monograph.

${ }^{1}$ Carl von Clausewitz, On War, trans. Michael Howard, Peter Paret, and Bernard Brodie (Princeton, NJ: Princeton University Press, 1984), 80.

${ }^{2}$ Department of the Army, Army Doctrine Reference Publication (ADRP) 3-0, Unified Land Operations (Washington, DC: Government Printing Office, October 2011), 9.

${ }^{3}$ Casper W. Weinberger, "U.S. Defense Strategy," Foreign Affairs 64, no. 4 (Spring, 1986): 675-97. 
The hypothesis of this monograph is that the commander can still practice effective operational art with ambiguous strategic objectives. Reading current doctrine, the operational commander would expect that the national level leadership provides clearly defined and attainable strategic objectives. However, history proves this is not always the case. Operational commanders should expect that the strategic guidance from the national level authority may be unclear and subject to change throughout the course of the operation. ${ }^{4}$ While the lack of clear strategic objectives may challenge the operational artist, the absence of clear objects provides the operational commander greater flexibility in arranging his operations in time, space and purpose.

\section{Purpose and Methodology}

The overall purpose of this monograph is to provide a perspective of operational art with ambiguous strategic guidance. To answer the research question and test the validity of the hypothesis this paper provides background research, doctrinal analysis, and a case study that demonstrate effective operational art with ambiguous strategic objectives. The paper's basic structure is a five-chapter monograph with Chapter One being a short introduction and Chapter Five the conclusion. Chapter Two presents a discussion of effective operational art with ambiguous strategic objectives. Chapter Three is in-depth case study of the American intervention in the Russian Civil War, specifically the American Expeditionary Force-Siberia. Chapter Four is the analysis of the case study in terms of the chosen theoretical construct. The overall goal of this paper is to provide insight to the practitioner about applying operational art with ambiguous strategic objectives and provide one concrete example of operational art under such conditions.

${ }^{4}$ Besides the case study example, the Vietnam War is another good example of strategic objectives that changed during the course of the war. 


\section{The Case Study}

The subject of the case study is the often overshadowed by other events in World War I. However, it provides a rich and colorful example of operational art under strategic ambiguity. In July 1918, President Woodrow Wilson made a controversial decision to support a multi-national coalition with an American military force to intervene in the Russian Civil War. The strategic reasons for Wilson's decision appear to be more diplomatic than militarily driven. There was a clear division in the Wilson's administration over which course of action to take concerning intervening in Russian internal affairs. ${ }^{5}$ After much consideration, Wilson committed approximately 13,000 soldiers split between two different campaigns in Russia. The American Expeditionary Force Siberia (AEF-S) with around 8,000 soldiers was the larger of the two American forces. They saw duty in the Eastern region of the Russian Empire primarily around the port city of Vladivostok. Wilson expressed his decision and rationale for authorizing military force in Russia in just a 1500 word document that formed the basis of his strategic guidance. In this document, known as Wilson's aide memoire, he provided ambiguous and conflicting objectives, which severely hampered the entire military operation in Siberia. ${ }^{6}$ Throughout the campaign, numerous operational challenges plagued the American efforts, including an overall lack of unity of effort among the Allies and a lack of coordination among the representatives of the U.S. government. After twenty months, the Americans ended military operations in Siberia with almost 200 dead and limited tangible results. ${ }^{7}$ Some critics blamed Major General William

${ }^{5}$ For a discussion on the Wilson administration's handling of the Russian revolution see David S. Foglesong, America's Secret War Against Bolshevism: U.S. Intervention in the Russian Civil War, 1917-1920 (Chapel Hill: University of North Carolina, 1995).

${ }^{6}$ Robert James Maddox, The Unknown War with Russia: Wilson's Siberian Intervention (San Rafael, CA: Presidio Press, 1977), 137.

${ }^{7}$ Robert L. Willett, Russian Sideshow: America's Undeclared War, 1918-1920

(Washington, DC: Potomac Books Inc., 2005), 267. 
S. Graves, the AEF-S commander, for the campaign's poor results. At first glance, it appears his critics are correct and this case study describes a failure in operational art. However, that is not the case. This monograph demonstrates that Graves performed extraordinarily well as an operational artist. Given the strategic context, he practiced effective operational art under the most difficult of situations. Throughout the campaign, Graves remained committed to the original strategic objective even though it limited his tactical options. ${ }^{8}$ In the end, the campaign concluded with limited tangible evidence of a classic military victory, yet General Graves demonstrates that a commander can practice effective operational art without clear strategic objectives.

${ }^{8}$ William S. Graves, America's Siberian Adventure: 1918-1920 (New York: Peter Smith Pub Inc, 1911). 


\section{CHAPTER 2: OPERATIONAL ART WITH AMBIGUOUS STRATEGIC OBJECTIVES}

goal. ${ }^{9}$

Direct every military operation toward a clearly defined, decisive, and achievable

Department of the Army, Army Doctrine Reference Publication, 3-0

\section{Operational Art Defined}

According to United States Army Doctrine Reference Publication 3-0, operational art is "the pursuit of strategic objectives, in whole or part, through the arrangement of tactical actions in time, space, and purpose." ${ }^{10}$ Although this definition is easily understandable, it lacks the necessary depth to gain an appreciation of operational art. By deconstructing the definition, students of operational art can better understand it. Operational art has two basic elements consisting of tactical actions and strategic objectives. Though current doctrine does not define the term tactical actions, one can infer that tactical actions are those that occur at the tactical level of war. ${ }^{11}$ Some classic examples of tactical actions include the Battle of Gettysburg, the Battle of the Little Big Horn, and the Battle of the Bulge. In turn, doctrine defines the tactical level of war as "the level of war at which battles and engagements are planned and executed to achieve military objectives assigned to tactical units or task forces."12 Therefore, when doctrine references tactical actions, the Army means battles or engagements.

However, the other component of operational art is more problematic. Like tactical actions, neither joint nor army doctrine define the term strategic objective. Deconstructing the term strategic objective, one creates an implied definition of the term. First, the term strategic is

${ }^{9}$ Department of the Army, ADRP 3-0, 4-1.

${ }^{10}$ Ibid.

${ }^{11}$ Department of the Army, Army Doctrine Reference Publication (ADRP) 1-02, Terms and Military Symbols (Washington, DC: Government Printing Office, 2013).

${ }^{12}$ Ibid., 1-57. 
derived from the strategic level of war, which is the "level of war at which a nation, often as a member of a group of nations, determines national or multinational (alliance or coalition) strategic security objectives and guidance, then develops and uses national resources to achieve those objectives." ${ }^{\prime 13}$ For simplicity sake, a strategic objective is essentially a national objective. This generates the question, what is an objective? Doctrine states it is "the clearly defined, decisive, and attainable goal toward which every operation is directed." ${ }^{14}$ Putting those two definitions together, strategic objectives are clearly defined, decisive, and attainable national goals toward which every operation is directed.

Military theory adds another level of understanding of operational art. The term operational art did not appear in literature until after World War I, found in the writings of Soviet theorists such as Aleksandr A. Svechin, Mikhail Frunze, and Georgii Isserson. Svechin, who is credited with coining the term, "described operational art as the bridge between tactics and strategy." ${ }^{\prime 15}$ In its earliest form, operational art enabled the linkage of strategy and tactics. The American military developed its version of operational art in the 1980s, based largely on the work of these Russian military theorists. Originally, the United States Army defined operational art as "the employment of military forces to attain strategic goals in a theater of war or theater of operations through the design, organization, and conduct of campaigns and major operations." 16 Over the course of three decades, the United States Army has continued to refine its definition of

\footnotetext{
${ }^{13}$ Chairman, Joint Chiefs of Staff, Joint Publication (JP) 3-0, Joint Operations (Washington, DC: Government Printing Office, 2011), GL-16.

${ }^{14}$ Department of the Army, ADRP 1-02, 1-41.

${ }^{15}$ Jacob W. Kipp, "The Origins of Soviet Operational Art," Historical Perspectives of the Operational Art, ed. Michael D Krause and Cody R Phillips (Washington, DC: Military Bookshop, 2010), 214.

${ }^{16}$ Department of the Army, Field Manual (FM) 100-5, Operations (Washington, DC: Government Printing Office, 1986), 10.
} 
operational art to the current version. The result is that theory and doctrine agree that operational art links tactical actions with the greater strategic objectives of a nation.

\section{Defining Strategic Objectives}

If operational art directs tactical actions towards achieving strategic objectives, it then begs the question: who defines those strategic objectives? According to Shimon Naveh, it is the "supreme political authority formulates the political-strategic aims and defines the strategic objective." ${ }^{\prime 17}$ Theoretically, the president, as the premier civilian and military leader of the country, is responsible for defining the strategic objectives. Doctrinally, the answer is not as clear. Current Army doctrine leaves this fundamental question unanswered; however, joint doctrine provides an answer to this question. According to Joint Publication 5-0, "the President and SecDef typically will establish a set of strategic objectives; however, in the absence of coherent guidance or direction, the CCDR/JFC may need to collaborate with policymakers in the development of these objectives." ${ }^{18}$ Furthermore, JP 5-0 directs the "commander and his staff to analyze all available sources of guidance" in order to define the associated military objectives and end state. ${ }^{19}$ In some cases, the onus of defining strategic objectives falls upon the military commander and not the civilian leadership. Even though this should not be the case, especially with civilian control of the military, the civilian leadership expects senior military leaders to formulate strategic objectives. History has shown examples of both scenarios. ${ }^{20}$ Sometimes the

\footnotetext{
${ }^{17}$ Shimon Naveh, In Pursuit of Military Excellence: the Evolution of Operational Theory (London: Routledge, 1997), 14.

${ }^{18}$ Chairman, Joint Chiefs of Staff, Joint Publication (JP) 5-0, Joint Operations Planning (Washington, DC: Government Printing Office, 2011), III-7.

${ }^{19}$ Ibid.

${ }^{20}$ Compare the American military experience in Operation Desert Storm with that of Operation Iraqi Freedom to see the role of military commanders in formulating strategic objectives.
} 
national leadership defines strategic objectives and sometimes it falls upon the operational commander to identify strategic objectives.

From this discussion, one fundamental question arises: can commanders exercise effective operational art with ambiguous strategic objectives? This question harkens back to discussions during the post-Vietnam era and even earlier to the Korean War era. During the Regan administration, two schools of thought developed regarding the use of military force and the importance of clearly defined strategic objectives. In a series of public speeches and articles, the two sides engaged in a running discussion about the use of military force in American foreign policy. ${ }^{21}$ On one side was the Defense Department, led by Secretary of Defense Casper Weinberger, and on the other the diplomats led primarily by Secretary of State George Shultz. ${ }^{22}$ Part of this discussion involved the importance of establishing clearly defined political and military objectives as a prerequisite for using military force. According to Weinberger, and to a greater extent the American military, the President and his advisors must establish clearly defined political and military objectives. ${ }^{23}$ On the other side, Schultz professed the Clausewitz maxim that war is merely the continuation of politics by others means, which could result in "gray areas" where this prerequisite did not apply. ${ }^{24}$ These gray area situations necessitate using military force for limited objectives that were diplomatic in nature, which could create ambiguity for the military.

In the end, the Weinberger doctrine came to define the ideal circumstances for the operational artist. If the President and his advisors conveniently hand the operational commander

\footnotetext{
${ }^{21}$ Christopher M. Gacek, The Logic of Force: The Dilemma of Limited War in American Foreign Policy (New York: Columbia University Press, 1994), 250-275.

${ }^{22}$ Ibid., 250-275.

${ }^{23}$ Weinberger, 675-97.

${ }^{24}$ Gacek, 264.
} 
a basic checklist of strategic objectives to achieve, then operational art becomes much simpler. The process that the Weinberger doctrine advocates seems to follow an unrealistic linearity in which the President determines to use military force, then lays out his strategic objectives and turns the entire mission over to the operational commander. In turn, the military commander achieves those objectives with the allocated resources and returns home victorious. The best example of this scenario is Operation Desert Storm. However, military campaigns are rarely this simple or easy and in reality, history has shown that it is usually not case. The Korean War, the Vietnam War and to an extent Operations Enduring Freedom and Iraqi Freedom are all examples refuting this aspect of the Weinberger doctrine.

What is more likely to occur is the use of military force under the umbrella of ambiguous strategic objectives. In this case, the establishment of strategic objectives is predicated on a dialogue between the operational commander and the strategic leadership. A helpful way to examine this relationship is in the context of a designer-client relationship. In this analogy, the operational commander is the designer and the strategic leaders are the clients. In the design world, the designer does not simply take directions from the client and build the project. According to one design expert, "it is certainly misleading to think that a client simply presents a designer with a complete brief." 25 At first, the client, in this case the president may only have a general idea regarding his ultimate objective. The designer, who is the commander, must then engage the client in an ongoing dialogue to collaborate on the development of the strategic objectives. Not only does this type of collaboration reduce the initial ambiguity of the strategic objectives, but it also allows the commander the flexibility to help define his desired end state.

\footnotetext{
${ }^{25}$ Bryan Lawson, How Designers Think: The Design Process Demystified, 4th ed. (Oxford: Elsevier/Architectural, 2006), 85.
} 


\section{Effective Operational Art with Ambiguity}

In order for the operational commander to practice effective operational art with ambiguous strategic objectives, he should follow a methodology of distilling the strategic objectives, defining the military objective, envisioning an end state, and developing an operational approach. As previously mentioned, the first step is reducing the ambiguity by fostering a dialogue and collaboration with the national leadership. In working to reduce the ambiguity, the commander can distill the strategic guidance into more definitive strategic objectives. He can then derive tangible military objectives that support the strategic objectives. The commander should use not only his own personal knowledge and experience in developing these objectives but rely on his staff to increase creativity and critical thinking. ${ }^{26}$ By developing tangible military objectives, the commander then can direct his military operation toward a clearly defined and achievable goal.

As the commander is considering his objectives, he should also envision an end state that supports those objectives. According to ADRP 3-0, "the end state is a set of desired future conditions the commander wants to exist when the operation ends. ${ }^{, 27}$ The end state assists the commander as an operational artist because it provides clarity for the mission and helps focus the operation on achieving strategic and military objectives. Typically, the end state includes military conditions but may also contain nonmilitary conditions if the situation warrants it. Closely associated with the end state are termination criteria, which are the specified conditions the commander must meet before an operation can conclude and normally represents the time beyond which the President does not require the military, as the primary means, to achieve remaining

\footnotetext{
${ }^{26}$ Department of the Army, ADRP 3-0, 4-1.

${ }^{27}$ Department of the Army, ADRP 3-0, 4-3.
} 
strategic objectives. ${ }^{28}$ Commanders should consider both end state and termination criteria early in planning to ensure the operation is achievable with the allocated resources.

After selecting the objectives and envisioning the end state, the commander creates his operational approach, which is the "description of the broad actions the force must take to transform current conditions into the desired end state." ${ }^{29}$ This is an excellent tool for the commander to practice effective operational art. The operational approach is the commander's visualization and description of the ends, ways, and means. "It should define what constitutes 'victory' or success (ends) and allocate adequate forces and resources (means) to achieve strategic objectives through the employing military capabilities (ways)." ${ }^{30}$ In order to create his operational approach, the commander should engage his staff in one of the military's design processes. ${ }^{31}$ By using a military design process, the commander not only develops his operational approach, but also forms the basis of his conceptual planning. By using a design methodology, the commander reduces more of the ambiguity by facilitating a great understanding of the operational environment and problem. The commander should then integrate the operational approach into the detailed planning process, which produces an operation plan that incorporates the strategic objectives, military objectives and desired end state.

The commander begins to develop his operational approach in the early stages of planning, and must continue to refine it throughout the planning process and the execution phase of the operation. By beginning to develop his operational approach early, the commander has time to reframe the objectives, end state, and the operational approach. Reframing enables the

${ }^{28}$ Chairman, Joint Chiefs of Staff, JP 3-0, I-8.

${ }^{29}$ Department of the Army, ADRP 3-0, 4-2.

${ }^{30}$ Chairman, Joint Chiefs of Staff, JP 5-0, III-7.

${ }^{31}$ The commander can select either the operational design process found in JP 5-0 or the Army design methodology found in ADP 5-0. 
commander to revisit his previous "hypotheses, conclusions, and decisions that underpin the current operational approach. ${ }^{, 32}$ Reframing should occur when operational conditions change, including the strategic context of the operation, requiring the commander to revisit his earlier analysis. In military operations with ambiguous strategic objectives, the strategic context is likely to change. In cases like this, the need to reframe periodically is imperative. Good examples of this are the Korean War and the Vietnam War where the strategic guidance from the president changed, necessitating the commander to reframe the objectives, end state, and operational approach. Reframing and refining the objectives, end state, and operational approach greatly improve a commander's practice of effective operational art.

\section{Conclusion}

Like most artistic media, a one-sentence definition does not adequately define the operational medium. Art is subjective, often defined by both form and content, and usually judged on the result of the artist's efforts or the final product. In this sense, operational art is not that different. Therefore, the operational commander must assess the effectiveness of his application of operational art based on his success in achieving the strategic objectives. Effective operational art often times involves taking ambiguous strategic guidance from the national leadership and translating it into a desired end state. Doctrine and theory can mislead the operational artist into believing that national level leadership will provide clearly defined and attainable goals. The operational artist must be prepared to work with ambiguous strategic guidance and build his operational plan based on his formulation and definition of the strategic objectives and end state. The next chapter examines a historical case that shows this to be true.

\footnotetext{
${ }^{32}$ Department of the Army, ADRP 5-0, 2-11.
} 


\section{CHAPTER 3: THE AMERICAN EXPEDITIONARY FORCE SIBERIA}

Watch your step; you will be walking on eggs loaded with dynamite. ${ }^{33}$

Newton D. Baker, Secretary of War

\section{$\underline{\text { Strategic Context }}$}

The spring of 1917 was a critical period for American foreign policy. During those critical months, two major events occurred that shaped American foreign policy over the coming century. First, the United States reversed years of publically declared neutrality and entered World War I alongside the Allied powers. Second, the Russian Tsar abdicated his throne. Initially, as Norman Saul observes "almost all Americans welcomed the February Revolution and the Tsar's abdication, assuming that the basic social structure and diplomatic alignment would continue." ${ }^{34}$ The Wilson administration viewed this as an opportunity to support democracy in Russia and the end of another problematic monarchy. However, Wilson and his administration never fully understood the true situation in Russia, which they considered a "backward land" that was yearning for freedom and democracy. ${ }^{35}$ Wilson placed his faith in the weak provisional government that came to power after the Tsar's abdication. However, now as a member of the Allied war effort, Wilson needed the Russians to continue fighting Germany rather than settling domestic issues. Subsequently, the Russian provisional government lasted only several months before Bolshevik forces seized power, precipitating the Russian withdrawal from World War I.

Economic interests have traditionally influenced American foreign policy and they certainly played a role in World War I. Prior to World War I, American businesses and diplomats perceived Russia as a land of opportunity. Many foreign observers saw Russia modernizing after

${ }^{33}$ William S. Graves, America's Siberian Adventure: 1918-1920 (New York: Peter Smith Publishing Inc., 1931), 4.

${ }^{34}$ Norman E. Saul, War and Revolution: The United States and Russia, 1914-1921 (Lawrence, KS: University Press of Kansas, 2001), 444.

${ }^{35}$ Maddox, 7. 
their stunning defeat in the Ruso-Japanese War. ${ }^{36}$ From the American perspective, Russia was both a lucrative source of natural resources needing an industrial base and a potential market to export their goods. As such, several large American companies made significant investments into the emerging Russian market. With the onset of war, Russia required increased material support from the Western world and the United States was poised to support them. However, one major problem existed. Prior to the war, American corporations relied on German intermediaries to facilitate the transfer of goods and bypass the complicated Russian tariff system. ${ }^{37}$ Once the Russians and Germans declared war on each other, this business arrangement no longer existed. In order to continue conducting business, they found new inland distribution channels including the ports of Vladivostok in the Far East and Archangel in the north, and the Trans-Siberian railroad. As the war continued, Russian reliance on American goods increased as did the importance of these ports and railroads to the Russian war effort.

The entire strategic situation changed in November 1917. Almost immediately after seizing power, the Bolshevik government sought to make peace with Germany. ${ }^{38}$ From the beginning, the British, French, and Japanese led a call for military intervention to prevent Germany from taking advantage of the crisis in Russia. The Allies feared that Germany would capture the strategic northern Russia ports of Murmansk and Archangel along with vast stores of military supplies in those areas. Additionally, they wanted to reopen the Eastern front by using the Czechoslovakian Legion in Russia to keep the Germans fighting in two directions. ${ }^{39}$ The pressure from foreign nations continued to mount over the course of the next year as the various

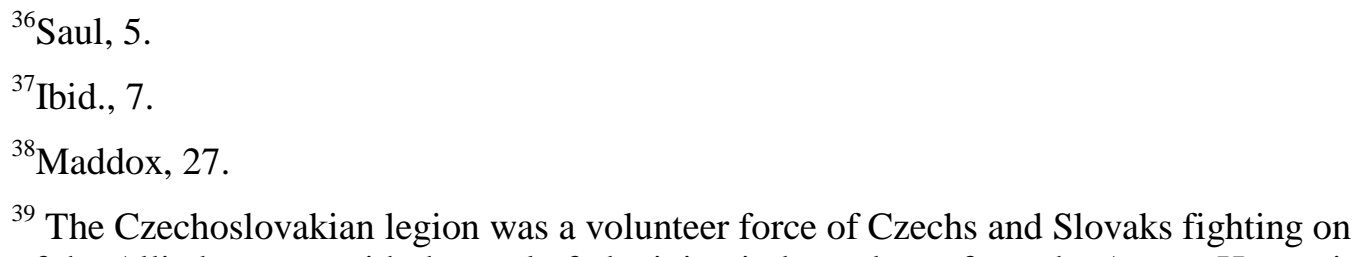

${ }^{39}$ The Czechoslovakian legion was a volunteer force of Czechs and Slovaks fighting on the side of the Allied powers with the goal of obtaining independence from the Austro-Hungarian empire following WWI. 
Allied powers advocated increased military interventionism. In March 1918, when the Bolshevik government signed the Treaty of Brest-Litovsk, the Allied powers faced the complete collapse of the Eastern Front. The Germans wasted no time in rushing forces to the Western Front and launched a spring offensive, which gained thirty miles and inflicted 120,000 Allied casualties. ${ }^{40}$ The Germans continued their offensive throughout the spring and early summer with increasing success. This triggered a major concern that the Germans could defeat the Allies on the Western Front before American forces arrived to bolster the Allied effort. ${ }^{41}$ In June 1918, Wilson acquiesced to British and French insistence on diverting American troops away from France and to Northern Russia, but not to a large-scale military intervention.

Domestically, Wilson faced a different kind of dilemma due to limited public and political support for the use of military force in Russia. ${ }^{42} \mathrm{He}$ already expended significant political capital making the case to enter World War I and could not sway domestic opinion to increase military involvement in world politics. Additionally, his personal long-term agenda to reshape the international landscape contributed significantly to the Russian dilemma. The Wilson administration failed to achieve a clear and unified consensus on a proposed military intervention in Russia. The Department of State was anti-Bolshevik and heavily favored supporting their Allies' proposals for an intervention in Russia. On the other hand, the War Department was adamantly opposed to such a military folly and squandering precious resources desperately needed on the Western Front. Over time, the combined efforts of the Allies and the American State Department won the argument and Wilson agreed to support a military intervention into Russia.

${ }^{40}$ Richard Goldhurst, The Midnight War: American Intervention in Russia, 1918-1920 (New York: McGraw-Hill, 1978), 3.

${ }^{41}$ Maddox, 45.

${ }^{42}$ Ibid. 


\section{The Decision to Intervene}

By July 1918, it became evident that Wilson was leaning towards approving a military intervention into Russia. However, the president still wanted to avoid the perception that the United States was mingling in the internal affairs of a foreign nation. One of the main factors of Wilson's hesitancy to intervene was his “conviction that America should deploy all its military and economic potential on the Western Front to assure a strong American position." ${ }^{43}$ The result consisted of the commitment of a military force with ill-defined strategic objectives. Publically, Wilson used the American assistance to the Czechoslovakian Legion along with the military necessity to guard the vast military stores in Russia to justify the military intervention. Wilson envisioned this assistance to the Czechoslovakian Legion as simply aiding the consolidation of their forces and their subsequent movement out of Russia. ${ }^{44}$ Additionally, he stated the military intervention could assist the Russian people in self governance or self defense in which they would be willing to accept. By couching the military operation as such, it appeared to garner widespread public support and domestic legitimacy. Privately his reasons for intervening were deeply rooted in his distrust of his Allied partners, especially the Japanese. This distrust was one of the major factors influencing his decision. President Wilson could not publicly declare that his true intention for sending a military force into Russia was to limit the various ambitions of England, France, and Japan. The British and French wanted to openly confront the Bolsheviks by using the combined efforts of the Allied intervention force, the Czechoslovakian Legion and antiBolshevik forces in Russia. The Japanese had the intention of using the military intervention as a means for acquiring territory in Siberia in order to create a buffer state. ${ }^{45}$ It would have been

${ }^{43}$ Saul, 309.

${ }^{44}$ Wilson did not want the Allies using the Czechoslovakian Legion to reopen the Eastern Front or as a proxy to fight the Bolsheviks.

${ }^{45}$ John F. Bradley, Allied Intervention in Russia, New York: Basic Books, 1968. 
politically disastrous to assert such distrust of his allies during the war. On the night of 16 July, President Wilson typed out the aide memoire, which would outline his rational and strategic guidance for the military intervention. Over the course of the next two years, this document served as the basis for the decisions made by the AEF-S operational commander. However, because of its cryptic nature, the aide memoire created confusion in both the United States War and State Departments.

The aide memoire contained conflicting messages intended for both domestic and foreign audiences. ${ }^{46}$ This message sought to assuage domestic fears regarding intent of the military intervention while warning the other Allies about having ulterior motives. In addition, it enabled, Wilson to reassure the Russians that this intervention was not an attempt to intervene in their domestic affairs. A single strategic message containing embedded messages for multiple audiences was doomed to fail. In the end, as Robert Willett notes, "it was a rambling, misguided document based on false assumptions and misinformation and was virtually impossible to comply with." ${ }^{47}$

With the decision to intervene, Wilson charged the War Department to plan and resource the effort. One of the first actions was the selection of a commander for the operation. Wilson based on the advice of Secretary Baker, selected MG Graves to command the AEF-S. ${ }^{48}$ Graves was a self reliant, experienced, and intelligent officer possessing the requisite qualities to lead such an ambitious expedition. ${ }^{49}$ Graves, having only recently assumed command of the Eighth Infantry Division, was training his unit at Camp Fremont, California for their upcoming

${ }^{46}$ Maddox, 53.

${ }^{47}$ Robert L. Willett, Russian Sideshow: America's Undeclared War, 1918-1920, (Washington, DC: Brassey's, Inc, 2003. Under “445,” Amazon Kindle edition.

${ }^{48}$ Maddox, 56.

${ }^{49}$ Goldhurst, 74 . 
deployment to the battlefields of France. On 2 August, Graves received a telegram from Washington that directed him to travel immediately by train to Kansas City to meet Secretary of War Newton Baker. Upon meeting in Kansas City, Baker gave Graves his new mission of leading the AEF-S. Baker then handed Graves a sealed envelope with his new orders and left him with a word of caution about the mission in Russia. ${ }^{50}$ Inside the envelope was Wilson's aide memoire, which would constitute the only written strategic guidance Graves received as he prepared to deploy his new force to Russia.

Graves immediately returned to his headquarters at Camp Fremont and began preparing to deploy to Russia. To form the nucleus of Graves' expeditionary force, the War Department selected two under strength regiments, the Twenty-Seventh and Thirty-First, both stationed in the Philippines. To augment these under-strength units, the War Department authorized Graves to deploy 5,000 soldiers from his own division. ${ }^{51}$ Within a month, the various Army units departed their locations in the Philippines and California for the Siberian port city of Vladivostok. These units had precious little time to prepare, equip, and train themselves for the unexpected mission. Overall, the Americans were unprepared and lacked a clear understanding of their mission, the conditions in Siberia, or even the strategic context of the intervention. The result was that the expedition, in the opinion of one scholar, "was a classic demonstration of an isolated and uninformed military subject to irrational government decisions. ${ }^{, 52}$

\section{The Operational Environment}

In the summer of 1918 , the operational environment in far eastern Russia was chaotic at best. Siberia, which is a territory the size of North America, had twenty-four separate

\footnotetext{
${ }^{50}$ Willett, under “3475,” Amazon Kindle edition.

${ }^{51}$ Edward M. Coffman, "The Intervention in Russia, 1918-1921," Military Review, 68, No 9 (1988): 63.

${ }^{52}$ Willett, under “445”, Amazon Kindle edition.
} 
governments bonded only by a hatred of Bolshevism and a distrust of Tsarists. ${ }^{53}$ Siberia presented a burgeoning humanitarian crisis with a huge influx of refugees with weak governmental authority and the virtual collapse of vital rail networks. The Russian population in Siberia was apolitical and according to Willett, "only wanted to go on with their daily lives without interference, preoccupied with scratching out a precarious livelihood. ${ }^{, 54}$ Further confounding the problem was the fact the Americans had arrived later than the other Allied Powers to Siberia. Because of geographic distance, Graves and his headquarters were the last American unit to arrive in Siberia. By the time the American commander arrived, the situation in Siberia was quickly deteriorating and they faced an uphill battle.

The two Philippines-based infantry regiments arrived several weeks earlier than the California-based units. ${ }^{55}$ Upon their arrival, the notional coalition commander, Japanese General Keijiro Otani, ordered the Americans to engage enemy forces north of Vladivostok. When Graves finally arrived, he found his American forces already involved in direct action against the perceived enemy and under the direct control of the Japanese command. Graves immediately took charge and addressed the confusion surrounding Japanese control of American troops. Initially, Graves at the request of the Japanese, allowed the Twenty-Seventh Infantry to participate in the Ussuri Campaign because "he reasoned that the battle was primarily against the elusive AustroHungarian German war prisoners." ${ }^{56}$ However, he made it clear to Otani that the American forces would work with the Japanese but would not answer to their orders.

${ }^{53}$ Maddox, 62.

${ }^{54}$ Willett, under "128”, Amazon Kindle edition.

${ }^{55}$ For discussion on troop strength, organization, and a basic summary of events see Order of Battle of the United States Land Forces in the World War (Washington, DC: United States Army War College, 1988), 385-389.

\footnotetext{
${ }^{56}$ Ibid., under “3770” Amazon Kindle edition.
} 
Compounding Graves's problems was the fact that American forces, thousands of miles away in Northern Russia, were actively fighting Bolshevik forces. Like the American force in Siberia, the American force in Northern Russia was also responsible for protecting the strategic ports, railways, and military stores in that area and not fighting the Bolsheviks. As there was no communication across Russia, Graves was unaware of events transpiring in the North. ${ }^{57}$ Although operating under the same strategic guidance that Wilson laid out in the aide memoire, the American forces in Russia operated under different constraints. The American force in Northern Russia was command by Colonel George Stewart. Surprisingly, the president placed Stewart under the direction of Ambassador David R. Francis. Francis was an adamant anti-Bolshevik who devised his own agenda instead of interpreting Wilson's policies. ${ }^{58}$ Thus for reasons outside of Graves control, by the fall of 1918 American neutrality largely did not exist throughout the Russian theater.

The AEF-S struggled with their partner nations but also openly fought with both Bolshevik and anti-Bolshevik forces in Siberia. The deplorable conditions in Siberia allowed guerilla bands on both sides to proliferate throughout the region. The Bolsheviks viewed the Allied military intervention as interfering in their internal affairs, regardless of Wilson's overtures in his aide memoire. The pro-Bolshevik forces openly opposed the Allied military forces throughout the campaign. Surprisingly, the force that may have caused the AEF-S the most trouble were anti-Bolshevik groups of Cossacks, operating under the auspices of the Japanese. Under the ruthless leadership of Gregory Semenoff and Ivan Kalmikov, the Cossack bands'

\footnotetext{
${ }^{57}$ Ibid., under “3720” Amazon Kindle edition.

${ }^{58}$ Goldhurst, 115 .
} 
undeclared mission was to terrorize the local populace using rape, theft, and murder. ${ }^{59}$ Under the guidance of the Japanese, the Cossacks' efforts intimidated the population but also prodded the Americans into action. The Japanese viewed the Americans as a barrier to gaining territory in Siberia and attempted to force the Americans into supporting their objectives or withdrawing from Siberia.

\section{The AEF-S Operations}

Upon his arrival in Siberia, Graves lacked the situational understanding of both the operational environment and the strategic complexity of their mission. He spent considerable time during his journey to Vladivostok studying the aide memoire and concluded that the primary military objective was assisting the Czech legion in moving to the Western Front. However, soon after arriving, he determined that the Allies had never intended sending the Czechs to the Western Front." ${ }^{, 60}$ Therefore, one of the publicly stated strategic objectives was a farce. It provided the Allied governments' political cover to gain public support for a military intervention in Russia. Yet it was never a realistic objective because the other Allied nations, including the Czechs, had no intention of proceeding to the Western Front in France. In fact, with the backing of the French and even some American diplomats, the Czech legion began a campaign against the Bolshevik forces in Russia. The French led the Czechs to believe that "Allied forces would be coming to relieve Czechs in the near future." ${ }^{61}$ As a result, the AEF-S placed very little emphasis on helping the Czechs leave Russia since it was a useless prospect from the start.

${ }^{59}$ Gibson Bell Smith, "Guarding the Railroad, Taming the Cossacks: The U.S. Army in Russia, 1918-1920," Prologue 34, no. 4 (Winter 2002): 1, http://www.archives.gov/publications/ prologue/2002/winter/us-army-in-russia-1.html (accessed 20 September 2013).

${ }^{60}$ Graves, 37.

${ }^{61}$ Willett, under "292" Amazon Kindle edition. 
By the middle of September, Graves began to understand that the true objectives of the Allied militaries in Siberia did not match their publically stated intentions. Subsequently, he concluded that his mission was diplomatic in nature rather than a military effort. He surmised that the French and English were undoubtedly trying to reestablish an Eastern Front and the Japanese were interested in a Far East land grab. ${ }^{62}$ Graves now faced a diplomatic nightmare and the potential for a military catastrophe. One the one hand he had to remain neutral to internal Russian politics. On the other hand, he had to support the publically stated goals of the Allies, while not embroiling himself in their ulterior motives. Thus, Graves settled on a course of action that would foster the perception of avoidance in the internal Russian politics while still supporting the stated goals of assisting the Russian people and protecting the American military supplies. Over the course of the next several months, the AEF-S executed a series of limited tactical actions that centered on the Trans-Siberia Railroad.

Even before Graves' forces arrived, there were already other American outfits operating in Siberia. The Russian Railroad Service Corp (RRSC) was a group of experienced railroad men who volunteered to salvage the vital Russian rail system. In May 1917, President Wilson commissioned a group of railroad executives to travel to Russia and advise the Russian interim government of recommendations for improving railroad operations. John Stevens, the leader of the RRSC, agreed to assist the inept Russian officials by providing a team of veteran American railroad operators. ${ }^{63}$ Although their efforts began in May 1917, the RRSC did not produce any tangible results until the spring of 1919, when the Allies, including China, reached an agreement concerning the operation of the Trans-Siberian Railroad. Nevertheless, the RRSC was the "first

\footnotetext{
${ }^{62}$ Graves, 63-65.

${ }^{63}$ Willett, under " 3280 ” Amazon Kindle edition.
} 
echelon of the American Intervention" and another actor that would significantly affect the AEFS' operations in Siberia. ${ }^{64}$

Overall, American troops primarily conducted garrison duty and guarded the railways and military stores while in Siberia. Generally, the Thirty-First Infantry remained close to Vladivostok while the Twenty-Seventh Infantry operated further in the interior. For the first few months, things were relatively quiet as the senior military commanders waged the game of diplomacy at the highest levels. Graves remained locked in a battle with both his Allied partners and the American State Department over the extent of military involvement in Russian internal affairs. Determined to remain neutral, the AEF-S agreed to protect part of the railroad and the Suchan coalmine, which Graves deemed essential to the operation of the railroad. ${ }^{65}$ Sensing that the war was almost over and still wary of the Allied governments' duplicity, the AEF-S only undertook such limited actions in the initial months of the campaign.

The signing of the armistice on November 11 should have ended the AEF-S mission, as the publically stated purposes of the intervention were no longer valid. ${ }^{66}$ However, this was not the case largely because the question of Russia's future was one of the main issues during the Paris Peace Conference. In fact, the State Department had informed the War Department that the "President would make no decision about ending the Russian intervention until after the peace conference." ${ }^{97}$ Wilson determined that the question of Russia's future was central to the discussions of the peace conference even though it was peripheral matter. The major Allied powers all recognized the potential menace that a Communist Russia presented but there were no other viable options. For political and military reasons, increasing the Allied military forces in

\footnotetext{
${ }^{64}$ Ibid., under “3281” Amazon Kindle edition.

${ }^{65}$ Coffman, 68.

${ }^{66}$ Maddox, 77.

${ }^{67}$ Goldhurst, 179 .
} 
Russia was untenable. The Allied governments needed a leader to unite the anti-Bolshevik effort in Russia and defeat the Bolshevik forces. Eventually, the Allied governments backed Admiral Alexander Kolchak, a former officer in the Imperial Russian Navy. In late November, Admiral Alexander Kolchak, with the covert support of the British, seized control of the Siberian government and called himself the Supreme Ruler of all Russia. However, it was not until several months later that all the Allied governments agreed to support Kolchak. The American's were the last to support Kolchak publicly, which would cause a great deal of problems for Graves.

While the fortunate events of November 1918 gave the Americans hope that their mission would soon end, this turned out to be a false hope. With the harsh Siberian winter setting in, the tension increased between the Allied military forces in Siberia. Japan continued to expand both its area of occupation and their troop strength. The situation worsened as the Allied forces, especially the Japanese and their surrogate Cossack bands, and Russian partisans turned the countryside into a scene of increasing devastation. ${ }^{68}$ The AEF-S remained committed to guarding the railroad and performing garrison duty. General Graves faced continuing pressure from both the Allied militaries and the State Department to support the anti-Bolshevik forces. Yet he remained committed to Wilson's strategic guidance and pushed to remain out of Russian affairs.

Stateside, the military intervention in Russia was proving just as problematic for the Wilson administration. Not only did Wilson face a divisive climate internationally but also domestic political support for the sustained intervention was deteriorating. According to Goldhurst "by the early spring of 1919 a tide of isolationism began to wash over the country which drowned even anti-Bolshevism." ${ }^{69}$ Led by Senator Hiram Johnson, Congress began to press the Wilson administration to resolve the Russian situation and bring the troops home.

\footnotetext{
${ }^{68}$ Willett, under “3894” Amazon Kindle edition.

${ }^{69}$ Goldhurst, 191.
} 
Additionally, American economic interest was a pressing concern for the Wilson administration. If the white Russians failed, then American businesses in Russia faced monumental losses instead of massive profits. ${ }^{70}$

Despite the growing pressure to bring the American forces home, the AEF-S remained in Siberia throughout 1919. In the spring, the Americans took a more active role in guarding the Trans-Siberian Railroad. With the signing of the Railroad Agreement by representative of the various Allied governments, the Americans assumed responsibility for guarding hundreds of miles of railroad lines. This new responsibility brought them into increased confrontations with pro-Bolshevik forces. While the agreement gave the Americans a specified mission, it also eroded the appearance of neutrality by protecting a railroad line used exclusively by the anti-Bolshevik forces. ${ }^{71}$ Graves became overly concerned about the Russians' perception that the AEF-S was now supporting the anti-Bolshevik forces. Therefore, he issued a proclamation directly to the Russian people articulating the true purpose of the AEF-S effort was "to protect the railroad and railway property and insure the operation of passenger and freight trains." ${ }^{, 72}$ Unfortunately for the Americans, their actions spoke louder than their words. By May 1919, the local partisans had determined the true intent of the Allies was not to ensure the fair and equal operation of the railroad, but instead was a measure of support for Kolchak.

The increased railroad guard duty placed the Americans in the cross hairs of local partisans resulting in the bloodiest months of the campaign. The Suchan Mine sector caused the Americans the most trouble, as it was the scene of gruesome violence between the Russian sides. Throughout the spring, the Americans encountered increased resistance in that sector. Graves ordered reinforcements to help quell the violence with no effect. In a series of increasingly lethal

\footnotetext{
${ }^{70}$ Ibid., 193.

${ }^{71}$ Willett, under “4237” Amazon Kindle edition.

${ }^{72}$ Graves, 186.
} 
battles, local partisans attacked the American forces. On 25 June, these attacks culminated in the single deadliest day for the Americans. During one engagement, known as the Romanovka Massacre, local partisans killed or wounded over half of one company. ${ }^{73}$ Throughout the summer, the Suchan Mine region remained volatile consisting of several clashes between the Americans and pro Bolshevik forces. These months also served as a turning point in the American operations, as the AEF-S withdrew from the more contentious areas and awaited their orders to redeploy.

Also in June 1919, a new phase in operations for the Allies in Siberia began. With the signing the Treaty of Versailles, any pretext of the Allied intervention in the Russian Civil War as a supporting effort to the Western Front ended. Wilson's previous rational for the Americans remaining in Siberia was no longer valid because the question of Russia's future was decided at the Paris Peace Conference. The Allies remained in Russia after June 1919 to wage an undeclared war on the Bolsheviks. On 12 June 1919, President Wilson finally agreed to provide Kolchak with material aid, which further supports the idea that the Allies remained in Russia to fight the Bolsheviks. ${ }^{74}$ Wilson's decision to support Kolchak presented a major problem for Graves on several levels. From the beginning of Kolchak's self-declared rule, Graves believed that Kolchak's government could not last. ${ }^{75}$ Additionally, Graves disapproved of Kolchak's method of governance, which included intimidation, torture, and murder of innocent civilians. For these reasons, supporting the Kolchak government, even covertly, to Graves was troublesome. Wilson's decision potentially signaled a change in strategic direction, which was even more problematic for Graves than his personal dislike of Kolchak. Graves attempted to clarify the apparent discrepancy between the president's decision and his original guidance by cabling the

\footnotetext{
${ }^{73}$ Maddox, 101-103.

${ }^{74}$ Graves, 355 .

${ }^{75}$ Ibid., 126.
} 
War Department to ask if the president intended to change his orders in conjunction with the decision to support Kolchak. The War Department's response and Wilson's public statement on June 26 both reaffirmed the noninterference policy. Subsequently, Graves' concluded that his original strategic objective was still valid. ${ }^{76}$ However, the State Department representatives in Russia viewed the president's intent differently for and believed Graves should fight the Bolsheviks. Throughout the summer, the State Department pressed him to support Kolchak and sent Roland Morris, Ambassador to Japan, to confront Graves directly on his lack of support for Kolchak. ${ }^{77}$ Unable to change Graves' resolve, the State Department continue to advocate unsuccessfully for Wilson to relieve him of command. Faced with increased diplomatic pressure and attacks by partisans, Graves remained committed to not interfering in internal Russian affairs.

By November 1919, Kolchak lost any hope of winning and fled for his life. As Willett describes "Western Siberia became a scene of total confusion and turmoil with the government, the Czechs, and refugees all seeking a way east." ${ }^{, 78}$ The conditions were quickly deteriorating, but Graves fretted about the loss of veteran soldiers throughout the fall of 1919. By December, his units had lost sixteen percent of their personnel and the few replacements that did arrive lacked combat experience. Fortunately, by the end of the month, Graves received redeployment orders from Washington to bring his troops home. As one scholar noted, "through it all, General Graves remained in command of the AEF-S and was continually pressured and harassed by virtually everyone", especially by his own State Department which on numerous occasions pressed the President to relieve Graves of command. ${ }^{79}$

\footnotetext{
${ }^{76}$ Ibid., 218-219.

${ }^{77}$ Ibid., 208-218.

${ }^{78}$ Willett, under "4926” Amazon Kindle edition.

${ }^{79}$ Ibid., under "4869” Amazon Kindle edition.
} 


\section{$\underline{\text { Results }}$}

When the last of the AEF-S forces left Vladivostok on 1 April 1920, there were few tangible results to show for their effort that produced one hundred eighty nine casualties. As Goldhurst writes, "the American intervention in Russia was the first intervention in which the United States could not even pretend it had accomplished what it set out to do" ${ }^{\text {80 }}$ Ultimately, the Czech legion left Russia, but by then the Treaty of Versailles was nearly a year old. The Allied effort to provide the Russians assistance in self-governance and self-defense turned out to be more problematic than productive. As for protecting American military supplies from German hands, the end of World War I seemed to make this objective no longer valid. This raises the question of why American Forces remained in Russia for so long. This question even puzzled General Graves who believed the signing of the armistice signaled the end of his mission, yet his force remained for many months afterwards. The answer to this question was one of international diplomacy and internal American disagreement over Communist Russia, not of military necessity. If Wilson had made his decision purely from a military perspective, then it was an easy choice to end operations in Russia with the conclusion of World War I. The decision to terminate the AEF-S mission early may have aided the perception that the American operation was a success and reduced some the criticisms of the AEF-S especially towards General Graves. However as this case demonstrates, military campaigns often become entangled in the greater geopolitical context.

The general response to the American's action in eastern Siberia was one of dissatisfaction and a belief that America was aiding the other side. The Allies, Bolsheviks, and anti-Bolsheviks all believed the Americans willfully supported the enemy. After the war, Graves became a target of anti-communists who labeled him a Bolshevik. In fact, Graves cites this undue

\footnotetext{
${ }^{80}$ Goldhurst, xv.
} 
criticism as a primary reason he published his memoirs from the expedition. Unfortunately, for Graves, some may judge him by the tangible results of his mission against the publicly stated goals from the Wilson administration. Considering the fact, Graves operated under the over arching principle of non-interference then the results take on a different meaning. Given what we now know, his contemporaries unfairly criticized Graves. In fact, a better description of Graves comes from one historian who wrote: "in the whole sad debacle, he may have been the only honorable man." 81

\footnotetext{
${ }^{81}$ Benson Bobrick, East of the Sun: The Epic Conquest and Tragic History of Siberia (New York: Poseidon Press, 1992), 368.
} 


\section{CHAPTER 4: ANALYSIS}

It is more difficult to come to a logical conclusion as to the reasons for intervention in Siberia by the United States, than that of any other nation. I can come to a conclusion, satisfactory to myself, as to why other nations took part, but have never been able to come to any satisfying conclusion as to why the United States ever engaged in such intervention."

-William S. Graves, AEF-S Commander ${ }^{82}$

\section{$\underline{\text { Introduction }}$}

Operational art begins and ends with strategic objectives. Thus, any analysis of an operational artist's performance ultimately reflects his ability to attain the president's strategic objectives. This can be problematic when the national leadership does not clearly define those strategic objectives. In such cases, other elements of operational art can help evaluate the effectiveness of an operational artist. These measures of effectiveness are distilling the strategic guidance into strategic objectives, deriving tangible military objectives from strategic objectives, envisioning a desired end state including termination criteria that support those objectives, and developing an operational approach that will that transform the current conditions into the desired end state. The case study demonstrates that these tasks can be quite difficult for the operational commander.

\section{$\underline{\text { Strategic Objectives }}$}

The most difficult task in analyzing the operational art of the AEF-S is determining what the true strategic objectives of its mission because Wilson never clearly stated his intent.

Publically, he specifically declared that the military force would not interfere in internal Russian affairs. It is clear from the aide memoire that he considered the American military intervention a

\footnotetext{
${ }^{82}$ Graves, 368 .
} 
limited operation and expected his coalition partners to limit their military operations as well. Privately, the president may have had ulterior motives for authorizing the use of military force in Russia. His true reasoning for undertaking the expedition remains a mystery. For the last century, historians have argued about Wilson's real purpose for the American military in Russia. There are two basic schools of thought concerning hidden motives for the intervention. One interpretation is that the real strategic objective was to support the anti-Bolshevik movement in Russia, supported by the fact that he eventually supported Kolchak in Russia. The other school of thought proposes that Wilson acted in Siberia to counter Japanese territorial ambitions and sustain America's open door policy in the Far East. ${ }^{83}$ Even Graves was "never able to come to any satisfying conclusion as to why the United States ever engaged in such intervention" although, he later concluded that his instructions listed in the aide memoire were not "frank and complete." 84 The president never sought to clarify the discrepancy between his publically stated objectives and his possible ulterior motives. Graves, who was not privy to the inner thoughts of the president, based his understanding of the strategic objectives largely on his analysis of the aide memoire. He received a copy of the aide memoire in Kansas City and spent abundant time analyzing the message in order to have a clear understanding of the president's policy and intent prior to arriving in Siberia. After thoroughly studying the aide memoire, he concluded that the most important strategic objective was refraining from interfering in the internal Russian affairs. ${ }^{85}$ Based on the little strategic guidance he received, Graves was correct in assuming his overall strategic objective was to avoid entangling his force in the Russian Civil War thereby necessitating an escalation of the intervention while still accomplishing his limited military objectives of assisting the

\footnotetext{
${ }^{83}$ See the comments of General Robert L. Eichelberger in Virginia Cooper Westall "AEF Siberia-The Forgotten Army," Military Review (March1968): 11-18.

${ }^{84}$ Graves, 343 .

${ }^{85}$ Ibid., 10.
} 
Czechoslovakian Legion and protecting the military stores from capture by the Germans. In arriving at his strategic objective, he is not solely at fault. By failing to define clearly his strategic objective, Wilson created ambiguity and disharmony, which plagued the entire campaign. This illustrates that Graves's overall analysis and conclusion of strategic objectives was correct based on Wilson's lack of strategic guidance.

\section{Military Objectives}

As stated in Chapter 2, the effective operational artist should translate strategic objectives into tangible military objectives. The first step in that process is reducing the possible inherent ambiguity associated with strategic objectives. The operational commander should seek a dialogue with the president to reduce the ambiguity and achieve a common understanding. ${ }^{86}$ To Graves's credit, he sought to reduce the ambiguity embedded in the strategic objectives in the aide memoire. However, Wilson never afforded the AEF-S commander the opportunity to discuss his strategic guidance directly, but instead sent Baker to deliver his guidance. Based on his meeting with Baker and his lengthy study of the aide memoire, Graves appropriately determined his overall strategic objective. Graves cabled the War Department multiple times requesting clarification of his strategic guidance as the situation in Siberia evolved. Each time, his superiors reiterated that he was to continue to follow the policy stated in the aide memoire until changed by the president. ${ }^{87}$ It is for these reasons that Graves remained committed to this strategic objective even in light of the antagonism of the State Department and Allies who sought a greater role for the American military force.

${ }^{86}$ In the early 1900 s, to communicate with the national level leadership in Washington, commanders either met face-to-face or used the telegraph.

${ }^{87}$ Graves, 218. 
Upon deciding his overall strategic objective, Graves focused on the military objectives for his mission. Taking the aide memoire at face value then the logical conclusion is that the Americans were in Russia for three major objectives. Those objectives were to assist the Czech legion in their movement to the Western Front via Vladivostok, support the Russians in selfgovernance or defense, and guard the military supplies in Siberia from the German-Austrian prisoners of war who were now free to operate within Russian territory. ${ }^{88}$ Those were the only publically documented objectives that President Wilson set forth in his message, and based on Graves's limited knowledge of the situation in Siberia, seemed prudent choices for military objectives. When the AEF-S arrived in Siberia, Graves decided on those three objectives as his military objectives. However, soon after his arrival, Graves realized the situation in Siberia did not support attaining those military objectives. First, the Czech legion never intended to leave Siberia and could operate virtually independently in Russia, requiring very little assistance from the Allies. Second, the threat of German-Austrian prisoners never materialized and the conditions surrounding the military supplies made safeguarding them nearly impossible. Last, any effort to support the Russians in self-governance or self-defense essentially violated the principle of noninterference. After gaining a better understanding of the operational environment, Graves wisely revised his original military objectives to simply guarding the railroad and settled for a less ambitious campaign.

\section{End State}

Based on his analysis of his strategic guidance and the overall situation, Graves rightfully concluded that the AEF-S played a subordinate role and supporting effort to the Western Front. His end state envisioned the AEF-S supporting the greater war effort by assisting the Czech legion in reaching the Western Front, denying the declared the German-Austrian enemy any

\footnotetext{
${ }^{88}$ Ibid., 7-8.
} 
military supplies that could be obtained in Siberia then shipped to the Western Front and supporting the Russians in self-defense and self-governance. Additionally the AEF-S had to balance these actions with the Russians perception of noninterference in their internal affairs. Ultimately, his end state envisioned the Allies wining World War I by defeating the enemy forces on the Western Front while the AEF-S accomplished limited military objectives in Siberia. ${ }^{89}$

Closely linked to the desired end state are termination criteria, which would allow the AEF-S to complete their mission and return home. Since the operation in Russia was a supporting effort to the Western Front, the logical conclusion was AEF-S would terminate military operations at the end of World War I. The only question was whether the armistice agreement of 11 November 1918 or the Treaty of Versailles signed on 28 June 1919 defined that specific termination criterion. The armistice proved problematic as termination criteria because Wilson deemed Russia central to the discussions at the peace conference. However, Graves was not aware that Wilson would tie the question of Russia's future to these negotiations until December 1918. Wilson's failure to share this strategic guidance prevented Graves from factoring it into his original end state. Likewise, the signing of the Treaty of Versailles should have ended the AEF-S missions and signaled the pending return of the troops. Unfortunately, for the AEF-S, Wilson's decision to support Kolchak in Russia would have major consequences for the American military force. His acquiescence to supporting Kolchak meant the AEF-S would remain in Russia as a conduit for supporting the anti-Bolsheviks. It also violated Wilson's original strategic guidance of noninterference, which invalidated the supporting objectives and desired end state. Graves attempted to rectify this problem with his superiors in Washington, but never received the clarification needed to revise his original objectives or end state. After June 1919, Graves struggled to redefine his desired end state and associated objectives and the AEF-S slowly began

\footnotetext{
${ }^{89}$ Graves, 144.
} 
withdrawing from military operations in Siberia. Eventually, the AEF-S returned home from Siberia, but the last ten months was challenging for Graves as an operational artist.

\section{Operational Approach}

After determining the objectives and end state, Graves developed an operational approach that supported his overall concept of operations. With the competing objectives of noninterference and assisting the Russians in self-governance and self-defense, Graves hesitated to undertake any major military operations. He settled on an operational approach that, according to Eichelberger, would "keep out of actual combat with the Reds, but keep open the TransSiberian Railway so that relief might pass over the line." ${ }^{90}$ Graves viewed the railroad as the center of gravity because of its importance to both the Russian populace and the Allied military force. Additionally, by limiting his efforts to maintaining the railroad, Graves believed that the AEF-S was not interfering in the Russian Civil War as both pro-Bolshevik and anti-Bolshevik could have used it. Of course, events show that this assumption was incorrect. Pro-Bolshevik forces perceived this action in as supporting the anti-Bolshevik forces, who had garnered exclusive use of the railroads due to assistance from the other nations. Overall, this operational approach was a logical choice based on AEF-S's original problem set, in the context of the operational environment and Graves's understanding of the strategic objective. Again, his original operational approach proved problematic when the strategic context changed after June 1919. Based on the summertime events, Graves revised his operational approach towards ceasing military operations and withdrawing from Siberia.

\footnotetext{
${ }^{90}$ Westall, 15.
} 


\section{Conclusion}

Scholars should judge Graves' operational artistry primarily on his ability to attain his strategic objectives, which was a monumental challenge because of Wilson's failure to articulate his true reason for the military intervention in Russia. If Wilson wanted the AEF-S to only support Allied actions on the Western Front, then Graves was successful for the AEF-S achieving this goal with minimal resources. If Wilson had simply wanted to appease his Allies, while not entangling the Americans in the Russian Civil War, then again Graves was successful. If Wilson wanted to stop Japanese territorial aggression and maintain the American open door in the Far East, then Graves was partially successful. Although the Japanese left Siberia after the Americans, they left Russia without gaining any new territory. If Wilson had grander designs for the military intervention as an anti-Bolshevik effort then Graves failed because eventually the Bolsheviks were able to consolidate their power throughout Russia soon after the Allies left Siberia. Ultimately, one must decipher Wilson's intent to be able to assess Graves's effectiveness as an operational artist.

Although one can debate Graves's overall effectiveness as an operational artist, his superiors' appraisal of his performance is less contentious. Even though numerous factions pressed Wilson to relieve Graves of command, Wilson never endorsed it. If Wilson had envisioned a different outcome from the AEF-S, he probably would have relieved Graves or issued new guidance directing a change in operations. Neither of those actions ever occurred, which supports the idea that Graves succeeded and Wilson was pleased with the outcome. Additionally, both Baker and Peyton March, then Chief Staff of the Army, thought highly of Graves and his handling of the military operation in Siberia. Throughout the campaign in Siberia, Graves received the continuous support of the War Department's civilian and military leadership, 
which helped bolster his standing with the president. ${ }^{91}$ Baker was so impressed with Graves'

performance that he authored the introduction to Graves' memoire in which wrote:

"Graves had the misfortune of being one of the first to command an armed force ordered to achieve limited diplomatic goals rather than military victory."

${ }^{91}$ Westall, 15-17. 


\section{CHAPTER 5: CONCLUSION}

This monograph demonstrates that a military commander can practice effective operational art with ambiguous strategic objectives. Doctrine, theory, and history all show that military operations must be directed towards clearly defined goals. Furthermore, current doctrine portrays the idea that the president will provide the operational commander with these clearly defined and attainable goals. However, history demonstrates this is not always the case. In reality, the operational commander should expect strategic guidance from the national level authority that may be unclear and subject to change throughout the course of the operation. This situation presents a unique challenge for the operational artist to overcome. He must first reduce the ambiguity of his strategic objectives in order to practice effective operational art. One technique borrowed from the design world is to foster a collaborative dialogue with the national level leadership. Reducing the ambiguity, clarifies the commander's strategic objectives so he can begin practicing effective operational art.

In this situation, effective operational art does not end with simply identifying the strategic objectives. The commander must continue the process of translating those objectives into tactical actions. He relies not only on his own personal experience and insights but must also leverage the collective knowledge of his staff. The process continues as he derives tangible military objectives and envisions a desired end state that supports the strategic objectives. This allows him to create an operational approach, which modifies the current conditions to achieve the desired end state. Furthermore, it enables the detailed planning of tactical actions. Although these steps facilitate effective operational art by reducing ambiguity inherent in strategic objectives, the commander must remain vigilant in indentifying and assessing changes in strategic and operational conditions that necessitate reframing. Reframing allows the commander to revisit his initial analysis and adjust his objectives, end state, and operational approach to address 
changes in conditions. By following this process, the commander, with the help of his staff, can practice effective operational art with ambiguous strategic objectives.

This monographs case study provides a remarkable example of exercising operational art with ambiguous strategic objectives as exemplified by Graves' performance in Siberia. Wilson produced ambiguous strategic objectives by never clearly articulating his ultimate rational and intent for the use of military force in Russia. Graves correctly recognized the challenging situation and attempted to reduce the ambiguity by fostering a dialogue with his superiors in the War Department. He rightly concluded that his overall strategic objective was to support the greater war effort while not interfering in Russian internal matters. Subsequently, he derived his military objectives, envisioned a desired end state, and developed an operational approach that supported his overall strategic objective. These are all hallmarks of effective operational artists.

Ultimately, people judge a commander on his ability to achieve the strategic objective. As the case study demonstrated, this form of judgment can be problematic when the strategic objectives are ambiguous. Throughout the campaign, Graves adhered to his strategic guidance and avoided undertaking any tactical actions that the Russians might construe as interfering in their internal affairs. Even though his decision brought him into direct confrontation with the State Department and the Allies, Graves refused to alter his objectives and operational approach until directed by the president. The unwavering support of the War Department and Wilson for Graves's performance in Siberia illustrates that he attained the strategic objective and excelled as an operational artist under difficult conditions. If Graves faltered as an operational artist, it may have been due to his reluctance to reframe his original analysis and conclusions after the strategic context changed in June 1919. However, to his credit, Graves sought to rectify the potential change in American policy towards Russia but never received a definitive answer. In the end, Graves achieved his original strategic objective of supporting the Allies without entangling the 
United States in the Russian Civil War. Overall, the case study demonstrates that a commander can practice effective operational art under the umbrella of strategic ambiguity. 


\section{BIBLIOGRAPHY}

\section{$\underline{\text { Books }}$}

Ackerman, Carl W. Trailing the Bolsheviki: Twelve Thousand Miles with the Allies in Siberia, 1890-1970. New York: Nabu Press 2010.

Arms, T. S. "Siberian Expedition: The Shktovo Sector, 31st Infantry, from September 1919 until the Withdrawal of the Expedition." Student paper, Command and General Staff College, 1931.

Baker, Ray S., ed. Woodrow Wilson Life and Letters: War Leader April 6, 1917-February 28, 1918. New York: Doubleday, 1939.

Bobrick, Benson. East of the Sun: The Epic Conquest and Tragic History of Siberia. New York: Poseidon Press, 1992.

Bradley, John F. N. Allied Intervention in Russia. New York: Basic Books, 1968.

Clausewitz, Carl von. On War. Translated by Michael Howard, Peter Paret, and Bernard Brodie. Princeton, NJ: Princeton University Press, 1984.

Echevarria, Antulio J. “American Operational Art, 1917-2008.” In The Evolution of Operational Art: From Napoleon to the Present, edited by John Andreas Olsen and Martin van Creveld, 137-165. New York: Oxford University Press, 2011.

Foglesong, David S. America's Secret War Against Bolshevism: U.S. Intervention in the Russian Civil War, 1917-1920. Chapel Hill: University of North Carolina, 1995.

Gacek, Christopher M. The Logic of Force: The Dilemma of Limited War in American Foreign Policy. New York: Columbia University Press, 1994.

Goldhurst, Richard. The Midnight War: American Intervention in Russia, 1918-1920. New York: McGraw-Hill, 1978.

Graves, William S. America's Siberian Adventure: 1918-1920. New York: Peter Smith Pub Inc., 1931.

Kennan, George Frost. The Decision to Intervene: Soviet-American Relations 1917-1920. Vol. 2. Princeton: Princeton University Press, 1989.

Kettle, Michael. Russia and the Allies, 1917-1920. Vol. 2. The Road to Intervention, MarchNovember 1918. London: Routledge, 1988.

Kindall, Sylvian G. American Soldiers in Siberia. New York: R. R. Smith, 1945.

Kipp, Jacob W. "The Origins of Soviet Operational Art." in Historical Perspectives of the Operational Art, edited by Michael D Krause and Cody R Phillips, 213-246. Washington, DC: Military Bookshop, 2010. 
Lawson, Bryan. How Designers Think: The Design Process Demystified. 4th ed. Oxford: Elsevier/Architectural, 2006.

Link, Arthur S., ed. The Papers of Woodrow Wilson. Vols. 46-53. Princeton: Princeton University Press, 1985.

Maddox, Robert James. The Unknown War with Russia: Wilson's Siberian Intervention. San Rafael, CA: Presidio Press, 1977.

Matheny, Michael R. Carrying the War to the Enemy: American Operational Art to 1945. Norman: University of Oklahoma Press, 2011.

Naveh, Shimon. In Pursuit of Military Excellence: The Evolution of Military Theory. Portland: Frank Cass, 1997.

Richard, Carl J. When the United States Invaded Russia: Woodrow Wilson's Siberian Disaster. Rowman and Littlefield Publishers, 2012.

Saul, Norman E. War and Revolution: The United States and Russia, 1914-1921. Lawrence: University Press of Kansas, 2001.

Schneider, James J. Vulcan's Anvil: The American Civil War and the Foundation of the Operational Art, Theoretical Paper No. 4. Fort Leavenworth: U.S. Army Command and General Staff College, 2004.

Seymour, Charles, ed. The Intimate Papers of Colonel House. Vols. 2, 3. Cambridge: Houghton Mifflin Company, 1928.

Swain, Richard M. "Filling the Void: The Operational Art and the U.S. Army." In Operational Art: Developments in the Theory of War, edited by B. J. B. McKercher and Michael Hennessey, 147-172. Westport: Praeger, 1996.

Unterberger, Betty M., ed. American Intervention in the Russian Civil War. Lexington: D.C. Heath and Co., 1969.

U.S. Army Center for Military History. United States Army in the World War, 1917-1919: Policyforming Documents of the American Expeditionary Forces. Vol. 2. Washington, DC: Government Printing Office, 1988.

Ward, John. With the Die-Hards in Siberia. Kessinger Publishing, 2004.

White, John Albert. The Siberian Intervention. New York: Greenwood Press, 1950.

Willett, Robert L. Russian Sideshow: America's Undeclared War, 1918-1920. Washington, DC: Brassey's, Inc., 2003.

\section{Articles, Papers, Theses, or Monographs}

Bolger, Daniel P. “Cruel Russia Winter.” Military Review 67, no. 6 (1987): 63-77.

Coffman, Edward. “The Intervention in Russia, 1918-1921.” Military Review 68, no. 9 (1988): 60-71. 
Cwiklinski, Carl. "America's Role in the Allied Intervention in Northern Russia and Siberia (1918-1920); Case Studies in Mission Creep and Coalition Failure.” Master's thesis, Naval War College, 1999.

Gorman, G. Scott. “Adapting to Chaos: American Soldiers in Siberia, 1918=1920.” Monograph, School of Advanced Military Studies, 1998.

Hayes, Harold B. “The Iron Horse from Nikolsk.” Military Review 62, no. 5 (1982): 18-28.

Isserson, G. S. "The Evolution of Operational Art.” Trans. Bruce W. Menning. Fort Leavenworth: SAMS Theoretical Special Edition, 2005.

Luckett, Judith A. "The Siberian Intervention: Military Support of Foreign Policy.” Military Review 64, no. 4 (1984): 54-63.

Morgan, David. "American Intervention in Russia, 1917-1918: A Study in Political-Military Relationships.” Master's thesis, Command and General Staff College, 1987.

Piatt, Walter E. "What is Operational Art?” Monograph, School of Advanced Military Studies, 1999.

Smalser, Robert L. "The Siberia Expedition 1918-1920: An Early Operation Other than War." Student paper, Naval War College, 1994.

Smith, Gibson Bell. "Guarding the Railroad, Taming the Cossacks: The U.S. Army in Russia, 1918-1920," Prologue 34, no. 4 (Winter 2002). http://www.archives.gov/publications/ prologue/2002/winter/us-army-in-russia-1.html (accessed 20 September 2013).

Westall, Virginia Cooper. “AEF Siberia- The Forgotten Army.” Military Review (March1968): 11- 18.

Weinberger, Caspar W. “U.S. Defense Strategy.” Foreign Affairs 64, no. 4 (Spring, 1986): 67597.

Wilson, Ross. “Operations Other Than War: U.S. Intervention into Russia 1918- 1920.” Student paper, National War College, 1994.

\section{$\underline{\text { Miscellaneous }}$}

Center of Military History, United States Army. Order of Battle of the United States Land Forces in the World War. Washington, 1988.

Chairman, Joint Chiefs of Staff. Joint Publication (JP) 3-0, Joint Operations. Washington, DC: Government Printing Office, 2011.

. Joint Publication (JP) 5-0, Joint Operations Planning. Washington, DC: Government Printing Office, 2011.

Department of the Army. Army Doctrine Reference Publication (ADRP) 1-02, Terms and Military Symbols. Washington, DC: Government Printing Office, 2013. 
Army Doctrine Reference Publication (ADRP) 3-0, Unified Land Operations.

Washington, DC: Government Printing Office, 2012.

Field Manual (FM) 100-5, Operations. Washington, DC: Government Printing Office, 1986.

Historical Files of the American Expeditionary Forces in Siberia, 1918-1920. National Archives and Records Service. Washington: 1973. 